ENVIRONMENTAL RESTORATION PROGRAM

\section{Waste Management Plan
for the Lower East Fork Poplar Creek \\ Waste Management Plan
for the Lower East Fork Poplar Creek \\ Remedial Action Project, Oak Ridge, Tennessee} ED

RECEIVED
NOV 041996

OSTI

This document has been approved for release to the public by the Y-12 Plant Techncial Information Office. Date: $8 / 30 / 96$ 
This report has been reproduced directly from the best available copy.

Available to DOE and DOE contractors from the Office of Scientific and Technical Information, P.O. Box 62, Oak Ridge, TN 37831; prices available from 423-576-8401 (fax 423-576-2865).

Available to the public from the National Technical Information Service, U.S. Department of Commerce, 5285 Port Royal Rd., Springfield, VA 22161. 
Energy Systems Environmental Restoration Program

\author{
Waste Management Plan \\ for the Lower East Fork Poplar Creek \\ Remedial Action Project \\ Oak Ridge, Tennessee
}

Date Issued-August 1996

Prepared by

Environmental Restoration Waste Management Division

Oak Ridge, Tennessee

Prepared for the

U.S. Department of Energy

Office of Environmental Management

under budget and reporting code EW 20

Environmental Management Activities at the

OAK RIDGE Y-12 PLANT

Oak Ridge, Tennessee 37831-8169

managed by

LOCKHEED MARTIN ENERGY SYSTEMS, INC.

for the

U.S. DEPARTMENT OF ENERGY

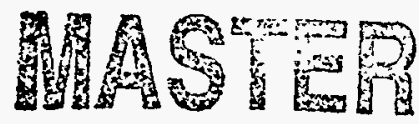

under contract DE-AC05-84OR21400 


\section{DISCLAIMER}

Portions of this document may be illegible in electronic image products. Images are produced from the best available original document. 


\section{DISCLAIMER}

This report was prepared as an account of work sponsored by an agency of the United States Government. Neither the United States Government nor any agency thereof, nor any of their employees, makes any warranty, express or implied, or assumes any legal liability or responsibility for the accuracy, completeness, or usefulness of any information, apparatus, product, or process disclosed, or represents that its use would not infringe privately owned rights. Reference herein to any specific commercial product, process, or service by trade name, trademark, manufacturer, or otherwise does not necessarily constitute or imply its endorsement, recommendation, or favoring by the United States Government or any agency thereof. The views and opinions of authors expressed herein do not necessarily state or reflect those of the United States Government or any agency thereof. 


\title{
APPROVALS
}

\author{
Waste Management Plan \\ for the Lower East Fork Poplar Creek \\ Remedial Action Project, \\ Oak Ridge, Tennessee \\ (Y/ER-264/R1)
}

Review and approval signatures indicate concurrence with and approval of the contents and intent of the Waste Management Plan for the Lower East Fork Poplar Creek Operable Unit, Oak Ridge, Tennessee.

LWayme Mismaho

Reviewed/by: L. W. McMahon, Environmental Compliance

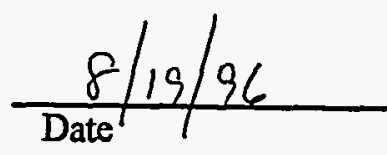

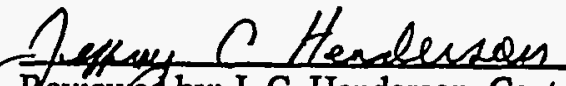

Beviewed by: J. C. Henderson, Central ER Waste Management

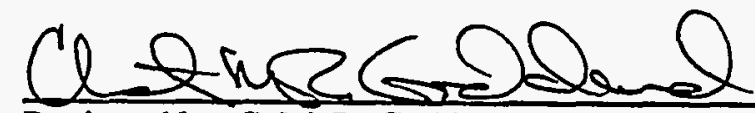

Reviewed by: C. M. R. Goddard, ER Pollution Prevention Program

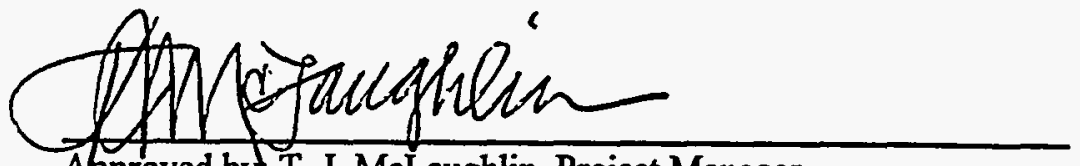

Approved by! T. J. McLaughlin, Project Manager

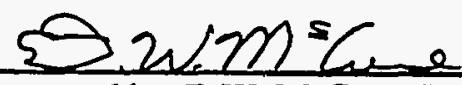

Approved by: D.W. McCune, Y-12 Waste Management

$\frac{F-16-96}{\text { Date }}$

$\frac{8 \cdot k-99}{\text { Date }}$

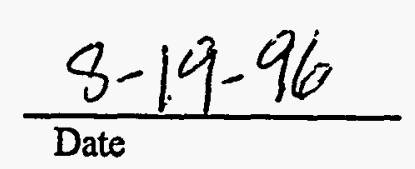

$\frac{8-19-96}{\text { Date }}$ 


\section{PREFACE}

This Waste Management Plan for the Lower East Fork Poplar Creek (LEFPC) Remedial Action Project, Oak Ridge, Tennessee (Y/ER-264/R1) was prepared in support of the Phase II Remedial Design Report (DOE/OR/01-1449\&D2) and in accordance with requirements under the Comprehensive Environmental Response, Compensation, and Liability Act of 1980 (CERCLA) to present the plan for waste management practices to be followed during the remediation. This work was performed under Work Breakdown Structure 1.4.12.3.1.04, Activity Data Sheet 9304 "Lower East Fork Poplar Creek." This document provides the Environmental Restoration Program (ER) with information about the waste handling, container and labeling requirements, waste characterization, transportation, waste staging areas, and disposal and waste minimization practices to be employed during the remediation project for the LEFPC Operable Unit. 


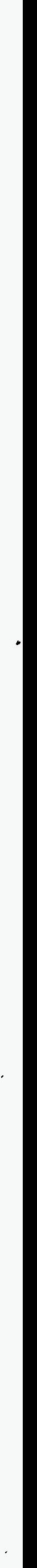




\section{CONTENTS}

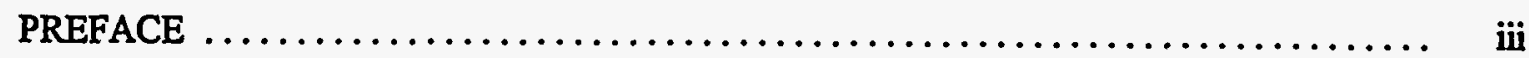

TABLES $\ldots \ldots \ldots \ldots \ldots \ldots \ldots \ldots \ldots \ldots \ldots \ldots \ldots \ldots \ldots \ldots \ldots \ldots \ldots \ldots \ldots \ldots \ldots \ldots \ldots \ldots$

ABBREVIATIONS $\ldots \ldots \ldots \ldots \ldots \ldots \ldots \ldots \ldots \ldots \ldots \ldots \ldots \ldots \ldots \ldots \ldots \ldots \ldots \ldots \ldots$

1. PROJECT DESCRIPTION $\ldots \ldots \ldots \ldots \ldots \ldots \ldots \ldots \ldots \ldots \ldots \ldots \ldots \ldots \ldots \ldots \ldots \ldots$

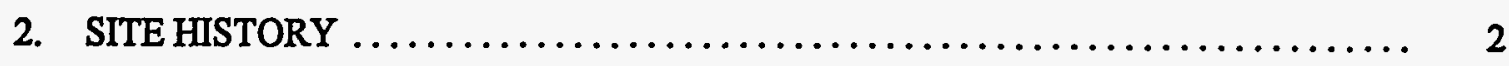

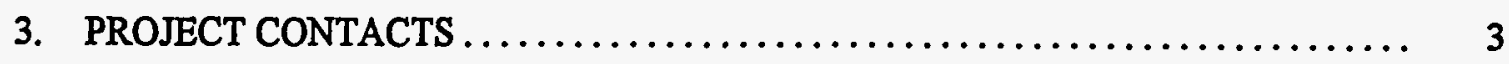

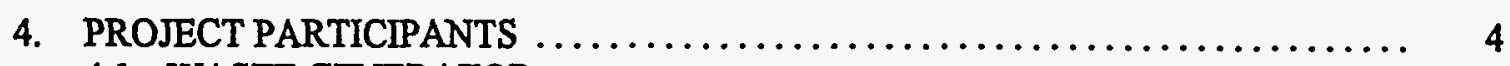

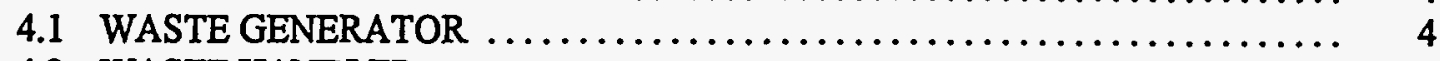

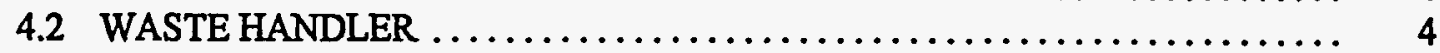

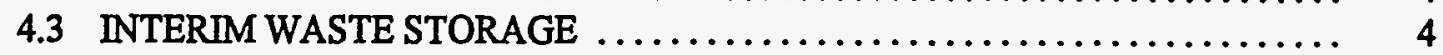

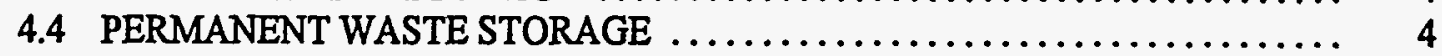

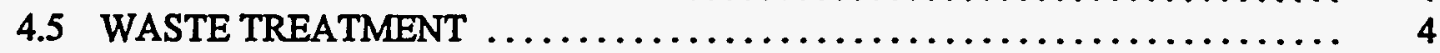

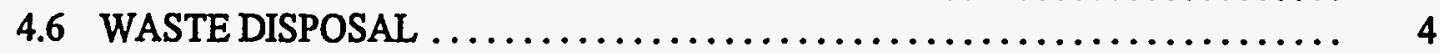

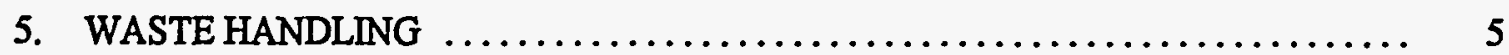

6. CONTAINER AND LABELING REQUIREMENTS $\ldots \ldots \ldots \ldots \ldots \ldots \ldots \ldots \ldots$

7. WASTE MANAGEMENT $\ldots \ldots \ldots \ldots \ldots \ldots \ldots \ldots \ldots \ldots \ldots \ldots \ldots \ldots \ldots \ldots \ldots \ldots \ldots$

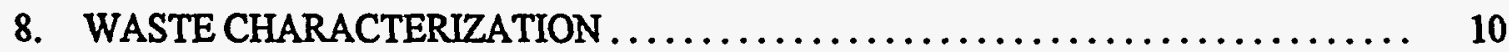

8.1 SUMMARY OF SOIL CHARACTERISTICS $\ldots \ldots \ldots \ldots \ldots \ldots \ldots \ldots \ldots \ldots, 10$

8.2 MERCURY CONCENTRATIONS CREEK SEGMENT 1 (NOAA) ........... 10

8.2 MERCURY CONCENTRATIONS CREEK SEGMENT 4 (BRUNER'S) ....... 11

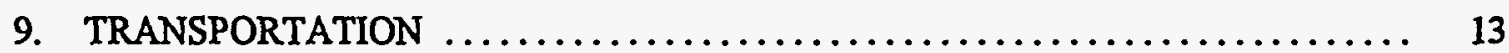

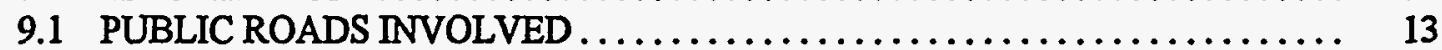

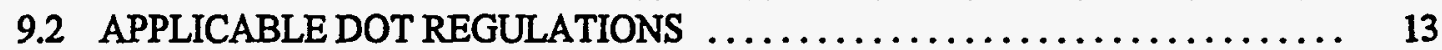

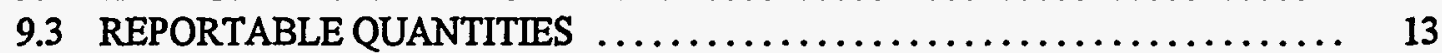

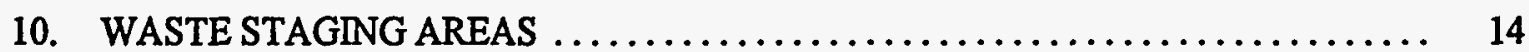

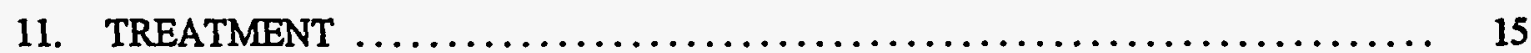

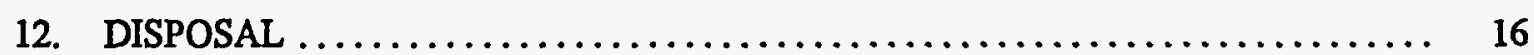

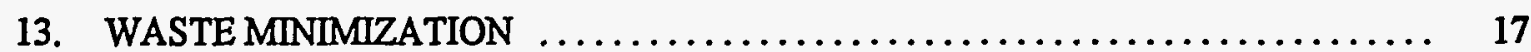

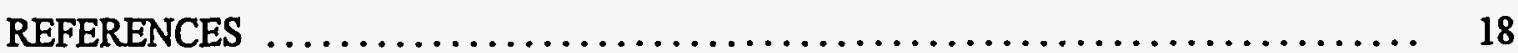


Appendix. WASTE ESTIMATE ASSUMPTIONS A-1 


\section{TABLES}

Table 3.1 Key Project Personnel $\ldots \ldots \ldots \ldots \ldots \ldots \ldots \ldots \ldots \ldots \ldots \ldots \ldots \ldots \ldots \ldots \ldots \ldots \ldots \ldots \ldots \ldots$

Table 7.1 Phase I Waste Volume Estimates $\ldots \ldots \ldots \ldots \ldots \ldots \ldots \ldots \ldots \ldots \ldots \ldots$

Table 7.2 Phase II Waste Volume Estimates $\ldots \ldots \ldots \ldots \ldots \ldots \ldots \ldots \ldots \ldots \ldots$ 


\section{ABBREVIATIONS}

$\begin{array}{ll}\text { C/D } & \text { construction/demolition } \\ \text { CERCLA } & \text { Comprehensive Environmental Response, Compensation, and Liability Act of } 1980 \\ \text { CFR } & \text { Code of Federal Regulations } \\ \text { CLP } & \text { Contract Laboratory Program } \\ \text { DOE } & \text { U.S. Department of Energy } \\ \text { DOT } & \text { U.S. Department of Transportation } \\ \text { EM } & \text { Environmental Management Program } \\ \text { EPA } & \text { U.S. Environmental Protection Agency } \\ \text { ER } & \text { Environmental Restoration Program } \\ \text { ESWMO } & \text { Energy Systems Waste Management Organization } \\ \text { FPSC } & \text { fixed-price subcontractor } \\ \text { IVC } & \text { independent verification contractor } \\ \text { km } & \text { kilometers } \\ \text { LEFPC } & \text { Lower East Fork Poplar Creek } \\ \text { Energy Systems } & \text { Lockheed Martin Energy Systems, Inc. } \\ \text { mg/1 } & \text { milligrams per liter } \\ \text { MK-F } & \text { MK-F of Oak Ridge Company } \\ \text { NCR } & \text { nonconformance reports } \\ \text { NOAA } & \text { National Oceanic and Atmospheric Administration } \\ \text { NPL } & \text { National Priorities List } \\ \text { ORR } & \text { Oak Ridge Reservation } \\ \text { OU } & \text { operable unit } \\ \text { PAH } & \text { polyaromatic hydrocarbon } \\ \text { PCB } & \text { polychlorinated biphenyl } \\ \text { POTW } & \text { publicly-owned treatment works } \\ \text { PPE } & \text { personal protective equipment } \\ \text { pCi/g } & \text { picocuries per gram } \\ \text { ppb } & \text { parts per billion } \\ \text { ppm } & \text { parts per million } \\ \text { PVC polyvinyl chloride } \\ \text { RCRA } & \text { Resource Conservation and Recovery Act of 1976 } \\ \text { RI } & \text { remedial investigation } \\ \text { ROD } & \text { record of decision } \\ \text { TCLP } & \text { toxicity characteristic leaching procedure } \\ \text { TDEC } & \text { Tennessee Department of Environment and Conservation } \\ \text { WCO } & \text { waste certification officer } \\ & \end{array}$




\section{PROJECT DESCRIPTION}

The Lower East Fork Poplar Creek (LEFPC) Remedial Action project will remove mercury-contaminated soils from the floodplain of LEFPC, dispose of these soils at the Y-12 Landfill V, and restore the affected floodplain upon completion of remediation activities. This effort will be conducted in accordance with the Record of Decision (ROD) for LEFPC (DOE/OR/02-1370\&D1, August 18, 1995) as a Comprehensive Environmental Response, Compensation, and Liability Act (CERCLA) action.

Upon completion of the work, mercury-contaminated soils $>400 \mathrm{ppm}$ will have been removed from specified areas within the LEFPC floodplain and placed in the Y-12 Landfill V. The excavated areas will have been restored through application of approved fill material and topsoil and revegetated similar to existing conditions. As part of this action, approximately one acre of wetlands will be disturbed and restored in accordance with regulatory requirements. In support of the remediation activities, site security will be established at each of the removal areas as well as access roads, staging areas, equipment decontamination areas, and soil drying areas. These site support facilities will be removed at the end of remediation, and the sites will be restored to approximate preproject conditions. In addition to the removal of contaminated soils, secondary wastes (e.g., decontamination water, excavation water) will be collected and appropriately disposed. These activities will be accomplished in two phases: (1) Phase I of the Remedial Action in 1996 to remediate soils from one site to accommodate commercial development and (2) Phase II of the Remedial Action for the remaining contaminated soils in 1997. The Phase I Remedial Action is scheduled to start July 1, 1996, and scheduled to be completed August 30, 1996. The Phase II Remedial Action is scheduled to start in April 1997 and be completed October 23, 1997.

Activities critical to the success of this project include the on-schedule construction of the Y-12 Landfill V and the timely verification of remediation completion by the Independent Verification Contractor (IVC). The project has assumed that access to the Y-12 Landfill V Cell 2 for the Phase II Remedial Action will be available by May 1997 and that the IVC will perform their function concurrently with the team's confirmatory sampling program.

The Waste Management Plan addresses management and disposition of all wastes generated during the remedial action for the LEFPC Project. Most of the solid wastes will be considered to be sanitary or construction/demolition wastes and will be disposed of at existing Y-12 facilities for those types of waste. Some small amounts of hazardous waste are anticipated, and the possibility of lowlevel or mixed waste exists (greater than $35 \mathrm{pCi} / \mathrm{g}$ ), although these are not expected. Liquid wastes will be generated which will be sanitary in nature and which will be capable of being disposed of at the Oak Ridge Sewage Treatment Plant (with the exception of sanitary sewage, which may be disposed of at any POTW chosen by service contractor. 


\section{SITE HISTORY}

The LEFPC Operable Unit (OU) site includes the soil, sediment, and groundwater within the 100-year floodplain along the LEFPC and the Sewer Line Beltway. The LEFPC OU begins at the outfall of Lake Reality at the Y-12 Plant and ends at the confluence with Poplar Creek, which is located $23.3 \mathrm{~km}$ downstream. The site includes portions of the Oak Ridge Reservation (ORR), as well as commercial, residential, agricultural, and other areas within the City of Oak Ridge. Due to releases of mercury and other contaminants from the Y-12 Plant since the 1950s, the floodplain downstream of the Y-12 Plant became contaminated. Contaminated soils outside the floodplain consist exclusively of floodplain soils used for backfill along the City of Oak Ridge Sewer Line Beltway.

In 1989, the ORR was placed on the National Priorities List (NPL) and designated as a CERCLA site. In accordance with CERCLA, and as agreed to in the Federal Facilities Agreement (FFA) between the Department of Energy (DOE), Environmental Protection Agency (EPA), and the Tennessee Department of Environment and Conservation (TDEC), a Remedial Investigation (RI) and Baseline Risk Assessment was conducted on LEFPC beginning in 1991 to define the extent of contamination and estimate the human health and ecological risk associated with the OU. Results of these studies identified mercury as the primary contaminant, contributing over $85 \%$ of the total toxicity. Other contaminants included other heavy metals, polyaromatic hydrocarbons (PAHs), polychlorinated biphenyls (PCBs), and low levels of radionuclides (primarily uranium isotopes), none of which were found to contribute substantially to the human health or ecological risks. Mercury contamination was found to be situated in defined areas along the floodplain, and at depths usually greater than $20 \mathrm{~cm}(8 \mathrm{in}$.) below the surface. Surface water, stream sediments, and Sewer Line Beltway soils were found to represent no significant human health or ecological risk.

The CERCLA decision-making process resulted in establishment of a remediation goal of 400 ppm for mercury in the floodplain. Based on this goal and additional sampling and analysis conducted since the $\mathrm{RI}$, specific areas have been identified that require remediation at the National Oceanographic and Atmospheric Administration (NOAA) site and at the Bruner site. The mercury contamination greater than $400 \mathrm{ppm}$ at the NOAA sites extends to a depth of approximately $40 \mathrm{~cm}$ (16 in.), while at the Bruner site, the depth extends up to $80 \mathrm{~cm}$ (32 in.) in some locations. Based on these depths and identified areas, the total identified volume of contaminated floodplain soils is approximately $35,000 \mathrm{yd}^{3}$. 


\section{PROJECT CONTACTS}

Names, affiliations, and telephone numbers of key personnel involved in the generation, management, and disposal of wastes in association with the LEFPC Remedial Action Project are identified in Table 3.1

Table 3.1 Key Project Personnel

Affiliation

ER Project Manager

Project Health and Safety Manager

Construction Manager

Design Manager

ER Waste Certification Officer

Y-12 Waste Management

Environmental Management
Name

Tom McLaughlin

Rudy Weigel

John McCollum

Robert Meccia

Jeff Henderson

Dave McCune

Wayne McMahon
Telephone

574-9249

241-2487

873-7370

481-8650

241-2410

$576-5280$

574-7535 


\section{PROJECT PARTICIPANTS}

\subsection{WASTE GENERATOR}

The Lockheed Martin Energy Systems, Inc. (Energy Systems) Environmental Restoration Program Waste Certification Officer (WCO) or Project Manager will be the generator of the waste and will ensure that wastes are properly certified, placed in containers, labeled, documented (including completion of Request for Disposal forms), and managed. The WCO will be responsible for the management of any 90-day storage areas which may be required at the remediation sites.

\subsection{WASTE HANDLER}

MK-Ferguson (MK-F) personnel will be responsible for waste generated by the Fixed Priced Subcontractor (FPSC) during Phases I and II of the project. The FPSC will be responsible for handling, containerizing, labeling, and transporting wastes generated during the project with oversight from MK-F, and Environmental Management (EM). Any Resource Conservation and Recovery Act of 1976 (RCRA) waste generated will be handled according to applicable federal regulations and may require transport by organizations other than MK-F and the FPSC.

\subsection{INTERIM WASTE STORAGE}

Interim storage will be provided at the sites for hazardous wastes and those nonhazardous wastes for which the appropriate disposition has not been identified. These issues are discussed in more detail in Section 10. Liquid wastes will be staged at the sites prior to treatment and after treatment, awaiting analytical results prior to disposal.

\subsection{PERMANENT WASTE STORAGE}

Energy Systems Waste Management Operations (ESWMO) personnel will be responsible for proper transportation to, receipt of , and storage of mixed waste delivered to the Oak Ridge K-25 Site or the Y-12 Plant.

\subsection{WASTE TREATMENT}

Waste treatment will be provided onsite for project-generated wastewater (wastewater is defined as any water which comes into contact with contaminated soil). Energy Systems is responsible for procurement of a package treatment system for this purpose. The FPSC will operate the system during Phases I and II of the project.

\subsection{WASTE DISPOSAL}

Most of the solid wastes will be disposed of at the Y-12 Landfill V or one of the Construction/Demolition Landfills. In general, waste waters will be disposed of to the City of Oak Ridge sanitary sewer system via the manhole designated on the design drawings. FPSC personnel will be responsible for this activity. 


\section{WASTE HANDLING}

Wastes generated by project activities will be stored, transported, and disposed of in accordance with applicable waste regulations and Department of Transportation (DOT) regulations, primarily DOT Federal Motor Carrier Safety Regulations, Hazardous Materials Regulations, and EPA regulations. MK-F will be responsible for assuring implementation of these regulations, while Energy Systems will provide oversight.

Y-12 Plant waste management procedures include:

- 70-903, Rev. 0 "Transfer of Waste to the Y-12 Plant ESWMO"

- 70-310, Rev. 0 "Waste Container Labeling"

- 70-303, Rev. 0 "Control of Industrial Wastes"

K-25 waste management procedures, which will be pertinent if hazardous wastes are generated which must be stored by Energy Systems, include:

- SPP-4600, Rev. 1 "Management of Wastes"

- SPP-4606, Rev. 1 "Waste Container Labeling"

The following waste acceptance criteria are applicable to all wastes going to the landfill:

- no free liquids present;

- storm drain pipe must be in sections less than 20 feet long to be disposed of at the landfill;

- the maximum size of root balls is eight feet and the maximum stump length is 18 inches; and

- floodplain debris can generally be disposed of at the landfill, with the exception of tires or other debris specifically excluded from disposal in Energy Systems landfills. Debris which is excluded from Energy Systems landfills will be the responsibility of MK-F or the FPSC.

In order to be received for burning at the Y-12 burn area, tree sections must be shorter than 10 feet in length. 


\section{CONTAINER AND LABELING REQUIREMENTS}

Most of the waste to be generated by the project will be transported to the landfill by truck. However during the course of the project it is possible that various floodplain debris (glass bottles, large metal pieces, etc.), and potential hazardous wastes (batteries, spray paint, etc.), could be generated which would have to be containerized for disposal. Possible container types would include, but not be limited to, 55- and/or 30-gallon drums and 5- or 10-gallon buckets. There is also a possibility that some waste may be required to be strapped onto pallets to be accepted at designated ESWMO facilities.

Waste which is transported by truck requires little or no labeling unless it contains reportable quantities of a hazardous material (for mercury the reportable quantity is $1 \mathrm{lb}$. per container). If hazardous materials are transported the trucks will be labeled in accordance with 49 Code of Federal Regulations (CFR) requirements. However, other wastes which must be containerized require labeling in accordance with Y-12 procedure 70-310 "Waste Container Labeling" (for waste destined for Y-12) and K-25 procedure SPP-4606, "Waste Container Labeling" (for waste destined for the $\mathrm{K}-25)$. 


\section{WASTE MANAGEMENT}

Tables 7.1 and 7.2 list the estimated volumes of waste anticipated during the two phases of the project. Actual volumes generated may vary from the values which appear in the tables. The assumptions upon which numbers in the table are based are listed in the appendix. In addition, the tables include information on the classification, characterization, packaging, transportation, and disposal of the wastes.

Most of the solid wastes will be classified as sanitary wastes and therefore will be disposed of at the Y-12 Sanitary Landfill or Construction/Demolition Landfill. Low levels of radioactivity do exist at the site, and thus the possibility of low-level or mixed waste generation exists, primarily for filters where material is concentrated. In the event that such waste is generated, the procedures cited in Section 5.0 will apply.

Management of wastes resulting from soil and water sampling activities is, in general, not listed specifically in these tables. A small amount of corrosive hazardous waste will be generated from analysis of soil samples and is included. Approximately $10 \%$ of the samples will be sent to offsite laboratories for analysis. The waste generated from these offsite analytical activities will not be returned and will not require management by Energy Systems, MK-F, or the FPSC. Wastes such as sampling equipment and trash associated with sampling activities is minimal and is considered to be included within the volume of sanitary solid waste cited in the tables. In the event that other hazardous wastes are generated during sampling activities or mixed wastes are generated during any project activity the WCO will ensure that they are properly certified, containerized, labeled, documented, managed and disposed of.

In addition, the following sanitary wastes will be generated during the surveillance and maintenance phase of the project (following the removal action), which will continue for five years.

- $120 \mathrm{~L}$ of creek sediment

- 150 starling carcasses remaining from tissue extraction

- 720 redbreast sunfish carcasses from tissue extraction 
Table 7.1 Phase I Waste Volume Estimates

\section{Waste Stream}

Contaminated soil and stumps

Small trees and branches

Stone

Sand

Removed grass and brush

Geotextile fabric and mat

Tree trunks

Truck bed/dewatering box liners

Sanitary solid waste

Broken pavement/gravel

Temporary fencing and gate

Hay bales

Sandbags

Floodplain debris

PPE

Storm drain pipe

Hazardous waste"

Spent filters

Spent activated carbon

Berm

Truck skirting

Silt fence

Dewatering water

Decontamination water

Excavation water

Sanitary sewage ${ }^{b}$

Soapy water/isopropanol

Analytical waste

TOTAL

"Not expected. 'To be disposed of by the subcontractor.

\begin{tabular}{|c|c|c|c|c|c|c|}
\hline Category & Contaminants & $\begin{array}{c}\text { Solid } \\
\text { Waste } \\
\text { Volume } \\
\text { (cublc feet) }\end{array}$ & $\begin{array}{l}\text { Lquid } \\
\text { Waste } \\
\text { Volume } \\
\text { (gallons) }\end{array}$ & Packaging & Transportation & Disposition \\
\hline Special & Mercury & 116,000 & NA & NA & Truck & Y-12 Landfill V \\
\hline Sanitary & Mercury & 52,000 & NA & NA & Truck & Burned at $Y-12$ \\
\hline Sanitary & None & 12,000 & NA & NA & Truck & $\mathrm{Y}-12 \mathrm{C} / \mathrm{D}$ Landfill \\
\hline Sanitary & None & 5,800 & NA & NA & Truck & $\mathrm{Y}-12 \mathrm{C} / \mathrm{D}$ Landfill \\
\hline Sanitary & None & 3,500 & NA & NA & Truck & Y -12 C/D Landfill \\
\hline Sanitary & Mercury & 3,500 & NA & $\mathrm{NA}$ & Truck & Y-12 Landfill V \\
\hline Sanitary & Mercury & 1,900 & NA & NA & Truck & Bumed at $Y-12$ \\
\hline Sanitary & Mercury & 740 & NA & NA & Truck & Y-12 Landfill V \\
\hline Sanitary & None & 700 & NA & Dumpster & Truck & Y-12 Landfill V \\
\hline Sanitary & None & 590 & NA & NA & Truck & Y-12 C/D Landfill \\
\hline Sanitary & None & 450 & NA & NA & Truck & Y-12 New Salvage Yard \\
\hline Sanitary & Mercury & 240 & NA & NA & Truck & Y-12 Landfill V \\
\hline Sanitary & None & 100 & NA & NA & Truck & $\mathrm{Y}-12 \mathrm{C} / \mathrm{D}$ Landfill \\
\hline Sanitary & Mercury & 53 & NA & NA & Truck & $\mathrm{Y}-12$ Landfill V \\
\hline Sanitary & Mercury & 34 & NA & Drum & Truck & $\mathrm{Y}-12$ Landfill V \\
\hline Sanitary & Mercury & 32 & NA & NA & Truck & Y-12 Landfill V \\
\hline Hazardous. & Unknown & 22 & NA & Drum & Truck & $\mathrm{K}-25$ storage \\
\hline Sanitary & Mercury & 15 & NA & Drum & Truck & Y-12 Landfill V \\
\hline Sanitary & Mercury & 9 & NA & Drum & Truck & Y-12 Landfill V \\
\hline Sanitary & None & 3 & NA & NA & Truck & Y-12 C/D Landfill \\
\hline Sanitary & Mercury & 3 & $\mathrm{NA}$ & NA & Truck & Y-12 Landfill V \\
\hline Sanitary & Mercury & 1 & NA & NA & Truck & Y-12 Landfill V \\
\hline Sanitary & Mercury & NA & 140,000 & NA & NA & Oak Ridge POTW \\
\hline Sanitary & Mercury & NA & 34,000 & NA & NA & Oak Ridge POTW \\
\hline Sanitary & Mercury & NA & 30,000 & NA & NA & Oak Ridge POTW \\
\hline Sanitary & None & NA & 10,000 & NA & Truck & POTW \\
\hline Sanitary & None & NA & 1,200 & Drum & Truck & Oak Ridge POTW \\
\hline \multirow[t]{2}{*}{ Hazardous } & None & NA & 2 & Drum & $\mathrm{NA}$ & $\mathrm{K}-25$ storage \\
\hline & & 7,692 & 215,200 & & & \\
\hline
\end{tabular}


Table 7.2 Phase II Waste Volume Estimates

Waste Stream
Contaminated soil and stumps
Small trees and branches
Stone and gravel
Removed grass and brush
Geotextile fabric and mat
Tree trunks
Truck bed/dewatering box liners
Sand
Temporary fencing and gate
Sanitary solid waste
Broken pavement/gravel
Floodplain debris
Hay bales
Hazardous waste
PPE
Spent filters
Storm drain pipe
Spent activated carbon
Sandbags
Silt fence
PVC pipe
Berm
Truck skirting
Dewatering water
Decontamination solution
Excavation water
Sanitary sewage
Analytical waste
Soapy water/isopropanol
Concrete curb/gutter

$\begin{array}{cc}\text { Category } & \text { Contaminants } \\ & \\ \text { Sanitary } & \text { Mercury } \\ \text { Sanitary } & \text { Mercury } \\ \text { Sanitary } & \text { None } \\ \text { Sanitary } & \text { None } \\ \text { Sanitary } & \text { Mercury } \\ \text { Sanitary } & \text { Mercury } \\ \text { Sanitary } & \text { Mercury } \\ \text { Sanitary } & \text { None } \\ \text { Sanitary } & \text { None } \\ \text { Sanitary } & \text { None } \\ \text { Sanitary } & \text { None } \\ \text { Sanitary } & \text { Mercury } \\ \text { Sanitary } & \text { Mercury } \\ \text { Hazardous } & \text { Unknown } \\ \text { Sanitary } & \text { Mercury } \\ \text { Sanitary } & \text { Mercury } \\ \text { Sanitary } & \text { Mercury } \\ \text { Sanitary } & \text { Mercury } \\ \text { Sanitary } & \text { None } \\ \text { Sanitary } & \text { Mercury } \\ \text { Sanitary } & \text { Mercury } \\ \text { Sanitary } & \text { None } \\ \text { Sanitary } & \text { Mercury } \\ \text { Sanitary } & \text { Sanitary } \\ \text { Sanitary } & \text { None } \\ \text { Sanitary } & \text { None } \\ \text { Sanitary } & \text { None } \\ \text { Hazardous } & \text { None } \\ \text { Sanitary } & \text { None } \\ \text { Sanitary } & \text { None } \\ & \\ & \end{array}$

TOTAL

Not expected.

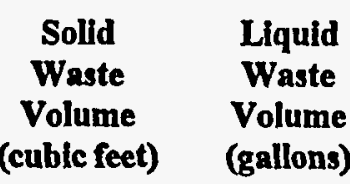

598,130
299,600
288,900
149,800
14,980
13,910
7,918
6,206
5,600
5,778
5,350
1,059
514
160
139
128
67
58
50
50
21
6
5
NA
NA
NA
NA
NA
NA
21

$1,398,450$

170,000

80,000

7
8,600

940,000

\section{Packaging Transportation}

Truck

Truck

Truck

Truck

Truck

Truck

Truck

Truck

Truck

NA $\quad$ Truck

Dumpster Truck

NA Truck

NA Truck

NA Truck

Drum Truck

Drum Truck

Drum Truck

NA Truck

Drum Truck

NA Truck

NA Truck

NA Truck

NA Truck

NA Truck

NA NA

NA NA

NA NA

$200,000 \quad$ NA

NA

NA

Drum

NA

\section{Disposition}

Y-12 Landfill V

Burned at $Y-12$

Y-12 C/D Landfill

Y-12 C/D Landfill

$Y-12$ Landfill $V$

Burned at Y-12

$Y-12$ Landfill $V$

Y-12 C/D Landfill

$Y$-12 New Salvage Yard

$Y-12$ Landfill $V$

$Y-12$ C/D Landfill

$Y-12$ Landfill $V$

Y-12 Landfill V

Off-site hazandous waste facility

Y-12 Landfill V

$Y-12$ Landfill $V$

$Y-12$ Landfill $V$

$Y-12$ Landfill V

$Y-12$ C/D Landfill

$Y-12$ Landfill V

$Y-12$ Landfill $V$

$\mathrm{Y}-12 \mathrm{C} / \mathrm{D}$ Landfill

$Y-12$ Landfill V

Oak Ridge POTW

Oak Ridge POTW

Oak Ridge POTW

$$
\text { POTW }
$$

Off-site hazardous waste facility

Oak Ridge POTW

Y-12 C/D Landfill 


\section{WASTE CHARACTERIZATION}

\subsection{SUMMARY OF SOIL CHARACTERISTICS}

The following summary of soil characterization is taken from data included in the special waste request submitted to TDEC in January 1995. Although the data indicates the presence of mercury at concentrations well below the removal standard of $400 \mathrm{ppm}$, only soil with concentrations above that level will be removed.

\subsection{MERCURY CONCENTRATIONS CREEK SEGMENT 1 (NOAA)}

Mercury concentrations in samples from creek segment 1 (NOAA) ranged from 30-1320 ppm (by neutron activation analysis) or $63-1590 \mathrm{ppm}$ [by EPA Contract Laboratory Program (CLP) analytical procedures]. Uranium ranged from 9.5-98 ppm with a range of enrichment from $0.03-0.85 \% \mathrm{U}-235$. Cesium-137 was found in concentrations from $0.57-8.24 \mathrm{pCi} / \mathrm{g}$, while americium-241, cobalt-60, neptunium-237, and protactinium-233 were all below $1 \mathrm{pCi} / \mathrm{g}$ maximum. The various isotopes of thorium were found at levels below $5 \mathrm{pCi} / \mathrm{g}$ maximum. Total uranium activity ranged from 13.3-50.7 pCi/g. The average activity is expected to be below $35 \mathrm{pCi} / \mathrm{g}$, which is the upper limit for disposal at the Y-12 Plant Sanitary Landfill. Organics were generally found in the ppb or low ppm ranges, with none of the usual volatile organics being present. Concentration ranges for the RCRA metals (mercury is discussed above) are listed as follows (separate ranges are listed if data from different analytical techniques were available):

Contaminant
Arsenic
Barium
Cadmium
Chromium
Lead
Selenium
Silver

\section{CLP Procedure}

$5.8-11.20 \mathrm{ppm}$

$99.1-327 \mathrm{ppm}$

$3.1-26 \mathrm{ppm}$

$34.7-67.4 \mathrm{ppm}$

$62 \mathrm{ppm}$

4.75-110 ppm

2.8-12.4 ppm

\section{Neutron Activation}

Analysis

1.8-14 ppm
NA
NA
$51.9-117 \mathrm{ppm}$
NA
NA
NA




\subsection{MERCURY CONCENTRATIONS CREEK SEGMENT 4 (BRUNER'S)}

For creek segment 4 (Bruner's), mercury concentrations ranged from 5.6-1390 ppm (by neutron activation analysis) or $225-1020 \mathrm{ppm}$ (by CLP procedure). Uranium ranged from $19-83 \mathrm{ppm}$ with a range of enrichment from 0.12-0.63\% U-235. Cesium- 137 was found in concentrations from 1.48$2.91 \mathrm{pCi} / \mathrm{G}$, while americium-241, cobalt-60, and neptunium-237 were all below $1 \mathrm{pCi} / \mathrm{g}$ maximum. Total uranium activity ranged from $21.5-31.8 \mathrm{pCi} / \mathrm{g}$. The average activity is expected to be below 35 $\mathrm{pCi} / \mathrm{g}$, which is the upper limit for disposal at the Y-12 Plant Sanitary Landfill. Organics were generally found in the ppb or low ppm ranges, with none of the usual volatile organics being present. Concentration ranges for the RCRA metals (mercury is discussed above) are listed as follows (separate ranges are listed if data from different analytical techniques were available):

\section{Contaminant}

Arsenic

Barium

Cadmium

Chromium

Lead

Selenium

Silver

\section{CLP Procedure}

6.1-15.1 ppm

$178-454 \mathrm{ppm}$

8.4-41.3 ppm

$71.5-112 \mathrm{ppm}$

$102-155 \mathrm{ppm}$

$3.52-16 \mathrm{ppm}$

10.3-29.7 ppm
Neutron Activation

Analysis

5.1-17.3 ppm
NA
NA
$48-180 \mathrm{ppm}$
NA
NA
NA

Soil samples from both the NOAA and Bruner's sites were tested for toxicity characteristic leaching procedure (TCLP) toxicity (sampling activity occurred from late March to early April 1995). The standard eight RCRA metals ( $\mathrm{As}, \mathrm{Ba}, \mathrm{Cd}, \mathrm{Cr}, \mathrm{Pb}, \mathrm{Hg}, \mathrm{Se}$, and $\mathrm{Ag}$ ) were not detected in the TCLP extract. Likewise, the RCRA organics were not detected, except for two volatile organic compounds. 2-Butanone was estimated up to $0.17 \mathrm{mg} / \mathrm{l}$ in a number of samples, but was also found in laboratory blanks. Tetrachlorethane was estimated in several samples at concentrations up to $0.0096 \mathrm{mg} /$. In both cases, all estimated concentrations are below the regulatory required detection limits. RCRA pesticides and herbicides were not detected. PCBs were found in two samples at estimated concentrations up to $0.0018 \mathrm{mg} /$, which is below the regulatory required detection limit, as well as the limit for disposal at Y-12. Based on this data, the soil can be classified as non-RCRA characteristic waste.

The waste waters are expected to contain minimal amounts of metals, as shown by the following data below. Radionuclides, which are present in the soil, are expected to be below detection limits. Organics are also not expected to be present above detection limits.

$\begin{array}{lr}\text { Beryllium } & 0.24-0.66 \mathrm{ug} / 1 \\ \text { Cadmium } & 4.3-8.8 \mathrm{ug} / 1 \\ \text { Chromium } & 5.7-12.1 \mathrm{ug} / 1 \\ \text { Copper } & 10.1-54 \mathrm{ug} / 1 \\ \text { Lead } & 8.3-11.3 \mathrm{ug} / 1 \\ \text { Mercury } & 13.8-121 \mathrm{ug} / 1 \\ \text { Nickel } & 6.5-16.6 \mathrm{ug} / 1 \\ \text { Selenium } & 3.9-15.9 \mathrm{ug} / 1 \\ \text { Silver } & 1.7-3.2 \mathrm{ug} / 1 \\ \text { Thallium } & 0.2-5.5 \mathrm{ug} / 1 \\ \text { Zinc } & 12.1-29.4 \mathrm{ug} / 1\end{array}$


Other solid wastes, such as activated carbon or filters, are likely to contain similar contaminants, but it is unknown at this time exactly what the levels of contamination will be. These materials will be sampled and analyzed prior to disposal to determine the appropriate waste classification and, thus, the appropriate disposition.

Additional sampling will be required for non-sanitary wastes to be disposed of at ESWMO facilities. These will have to be characterized and certified in accordance with ES/WM-10 Waste Acceptance Criteria for the Oak Ridge Reservation. The Environmental Restoration Organization has in place an approved Waste Certification Procedure ERWM/ER-P2109, "Environmental Restoration and Waste Management Organization Waste Certification," which will be followed to properly certify wastes generated during the Lower East Fork Poplar Creek Project. The procedure calls for specific project waste information to be provided to the Site Waste Certification Group through completion of Appendix $\mathrm{C}$ of the above mentioned procedure. The Waste Certifier will complete the required information and any necessary revisions needed to receive authorization to certify waste. Any hazardous waste generated during the LEFPC project will be characterized using the most accurate and cost efficient method(s) including but not limited to documented process knowledge and/or sampling and analysis. 


\section{TRANSPORTATION}

\subsection{PUBLIC ROADS INVOLVED}

During Phase I of the project, wastes will be transported from the NOAA site utilizing Woodbury Lane, Wilberforce Ave., Tulsa Rd., Illinois Avenue, Scarboro Road, and Bethel Valley Road. Phase II will utilize only the latter three thoroughfares for transportation from the NOAA site.

During Phase II, wastes will be transported from the Bruner's sites utilizing the Oak Ridge Turnpike, Illinois Avenue, Scarboro Road, and Bethel Valley Rd.

If hazardous waste is generated which must be transported to and stored at the $K-25$, the same roads will be utilized, with the exception of Bethel Valley $R d$.

\subsection{APPLICABLE DOT REGULATIONS}

49 CFR 171-173, 177 DOT Hazardous Materials Regulations

49 CFR 382-399

Federal Motor Carrier Safety Regulations

\subsection{REPORTABLE QUANTITIES}

The reportable quantity for mercury is $1.0 \mathrm{lb}$ per container or conveyance (drum, truck, etc.). If amounts of waste are spilled which result in the release of more than one pound, based on the total mass and the concentration, this is reportable. A 25-cy truckload could potentially contain anywhere from $25-50 \mathrm{lb}$ of mercury at average concentrations of $400-600 \mathrm{ppm}$, or up to $120 \mathrm{lb}$ at a maximum concentration of $1590 \mathrm{ppm}$.

If hazardous wastes are discovered during the excavation, they should be identified and the hazardous materials table in 49 CFR 172-101, Appendix A should be consulted to determine reportable quantities.

In general, the reportable quantity for D002 (corrosive) waste, such as will be generated during on-site analytical activities, is $1.0 \mathrm{lb}$. However, the regulatory citation reference above should be consulted to determine the reportable quantity of the particular acid involved. If elementary neutralization is conducted to eliminate the hazardous characteristic, this issue does not apply. 


\section{WASTE STAGING AREAS}

The FPSC will be responsible for any hazardous waste generated during the project. Since the project fits the definition of a small quantity generator RCRA areas are not required. However due to the uncertainties concerning the amounts and types of RCRA waste that could potentially be encountered during excavation of flood plain soils the possibility exists that 90-day accumulation and/or satellite areas may be necessary. If RCRA areas are established at the site they will be managed by the WCO. The WCO will assure that the waste is secured during periods when Energy Systems, MK-Ferguson and FPSC personnel are not at the site. Securing the waste could include but not be limited to, locking container lids, securing the waste in a trailer or storage building or in a fenced in area with controlled access. In the unlikely event that mixed waste is generated during the project it will be transferred to $\mathrm{K}-25$ or $\mathrm{Y}-12$ for storage.

Non-RCRA materials without obvious dispositions will be staged on-site until the appropriate disposition can be determined. 


\section{TREATMENT}

Treatment for solid wastes will consist of dewatering of excavated soils at the site and burning of tree trunks at Y-12.

Treatment will be provided for project-generated wastewater. A packaged waste water treatment system utilizing filters and carbon adsorption cartridges will be utilized to remove particulates and mercury. Small storage tanks will be used to collect the water for treatment and for sampling/analysis prior to disposal after treatment. No secondary containment of wastewater tanks will be provided since the wastewater is not considered to be hazardous waste. 


\section{DISPOSAL}

Most of the solid wastes generated by the project will be disposed of at the Y-12 Landfill V (under the provisions of a special waste permit from TDEC) or one of the Y-12 Construction/Demolition (C/D) Landfills. Sanitary trash will be disposed of at the Y-12 Landfill V.

Wastewater will generally be discharged to the Oak Ridge POTW via the nearest sanitary sewer manhole. Specific discharge limits and sampling requirements will be established via the permit with the City of Oak Ridge and compliance with these will be required prior to any discharge to POTW. Sanitary sewage will be disposed of by the subcontractor.

Hazardous and other waste not suitable for landfill generated during the project will be the responsibility of the FPSC and will be disposed of at an approved off-site facility. In the unlikely event that mixed waste are generated they will be transported to $\mathrm{K}-25$ or $\mathrm{Y}-12$ for storage. 


\section{WASTE MINIMIZATION}

Every attempt will be made in the field to avoid the generation of low-level or mixed waste if possible (e.g., by minimizing inventories of waste materials in filters, etc.).

Equipment will be decontaminated with water to remove residual mercury contamination and allow reuse. It may also be possible to decontaminate disposable construction materials such as pipe to allow disposal in a Y-12 Construction/Demolition Landfill rather than Landfill V. Decontamination solutions will be treated on-site, analyzed, and recycled to the maximum extent practical.

The volume of excavated soils will be minimized by excavation of layers of soil followed by sampling to determine whether the limits of excavation have been reached. Continued sampling is also being used to better define the areas of soil requiring excavation.

Personnel protective equipment volumes should be minimized by limiting the number of personnel entries into the exclusion zone and the contamination reduction zone and using launderable PPE instead of disposable materials.

Sanitary waste should be minimized by providing recycling opportunities for corrugated cardboard, mixed paper, and aluminum beverage cans.

Fencing should be stockpiled for reuse or dispositioned for recycling.

Stockpiling of materials, such as sand, stone, and gravel should be considered to avoid disposal and to avoid costs to future projects. Geotextile fabrics, mats, and berm materials from decontamination areas which are in good condition should be stored for similar use in the future.

Hazardous wastes from analytical activities, which are hazardous due to low $\mathrm{pH}$, may be able to be minimized by being neutralized in the laboratory. 


\section{REFERENCES}

ES/WM-10. Waste Acceptance Criteria for the Oak Ridge Reservation

ES/WM-34. Pollution Prevention Opportunity Assessment of Personal Protective Equipment Use on the U.S. Department of Energy Oak Ridge Reservation, Oak Ridge, Tennessee. January 1995.

Crabtree, J. P., letter to L.L. Radcliffe, Notice of Special Waste Approval, \#0 1-0089, September 15, 1995.

Crabtree, J. P., letter to L. L. Radcliffe, Notice of Special Waste Approval, \#01-0096 (revised), May 17, 1996.

Butz, T. R, letter to R. C. Sleeman. Notification of Planned Open Burning Events to be Conducted in the Bear Creek Burial Grounds Located West of the Y-12 Plant Plant.

Memorandum of Understanding Between LEFPC Project and Y-12 Waste Management Operations.

Metcalf \& Eddy, Inc., Wastewater Engineering: Treatment, Disposal, Reuse. Third Edition, 1991, McGraw-Hill.

Wastewater Discharge Permit from City of Oak Ridge

K-25 Standard Practice Procedures

SPP-4600, Rev. 1 Management of Wastes

SPP-4606, Rev. 1 Waste Container Labeling

Y-12 Plant Procedures

70-903, Rev. 0 Transfer of Waste to Y-12 ESWMO

70-310, Rev. $0 \quad$ Waste Container Labeling 
Appendix

WASTE ESTIMATE ASSUMPTIONS 


\section{WASTE ESTIMATE ASSUMPTIONS}

1. Volume estimates were taken from the project cost estimate wherever possible.

2. The volume of removed grass and brush was estimated by multiplying the area of removal by three inches, per FWENC.

3. The volume of all plastic waste streams was estimated by calculating their actual volume, then multiplying by a factor of 14.5 , which is the approximate ratio of the actual material density to that of uncompacted residential plastic waste. Dewatering box liners were assumed to be the same volume as that of the truck bed liners, which were based on 288 square feet per truck, 15 cubic yards per truck, and the total volume of soil being hauled.

4. The volume of trees to be sent for burning was assumed to be 10 times greater than the amount of chipped wood originally included in the estimate.

5. The volume of sanitary solid waste was estimated from the Y-12 1994 per capita generation rate of 230 cubic feet per year per person times an estimation from the cost estimate of the total hours involved in each phase (about 6,100 for Phase I and 48,800 for Phase II).

6. The volume of broken pavement and gravel was determined by multiplying the area involved by 3 inches, which was the depth of replacement paving.

7. The volume of temporary fencing and gates was calculated assuming 7-ft chain-link, with sections stacked 1-1/2 inches apart (half of the assumed 3-in post diameter).

8. The volume of individual hay bales was assumed to be 5 cubic feet.

9. The volume of floodplain debris was calculated from the estimated weight using the density of noncombustible commercial rubbish (about 19 pounds per cubic foot).

10. The volumes of storm drain pipe and plastic pipe were calculated using the appropriate lengths and diameters.

11. The volume of hazardous waste was assumed to be equivalent to the volume of the containers procured for storing the hazardous waste.

12. Calculations of the volume of PPE were based on 28 changes per day (20 in the exclusion zone and 8 in the decontamination area) with durations of 24 days for Phase I and 86 days for Phase II. PPE was assumed to be approximately equivalent in each area, consisting of paper or Tyvek suits, gloves, and booties. The total weight of a suit was calculated to be about $23 \mathrm{oz}$, based on data in ES/WM-34, Pollution Prevention Opportunity Assessment of Personal Protective Equipment used on the U.S. Department of Energy Oak Ridge Reservation, Oak Ridge, Tennessee (January 1995). This document also stated that a 55-gal drum will hold $200 \mathrm{lb}$ of PPE.

13. Spent filter volumes were assumed to be equivalent to the associated container volumes. 
14. Spent carbon volumes were calculated based on generation rates of $650 \mathrm{lb}$ for Phase $\mathrm{I}$ and 4000 $\mathrm{lb}$ for Phase II, using a wet, drained density for Calgon Filtrasorb 300 of 74 pounds per cubic foot.

15. The volumes of the berms, which are basically inflatable pillows, were calculated assuming that they extended the perimeter of the decontamination pads, were one foot wide, and consisted of two thicknesses of 6 mil plastic, with twice that volume of residual air. The bulk volume was calculated the same way as other plastic streams.

16. Silt fences were assumed to be 3 feet high and consist of 2 mil plastic.

17. Sanitary sewage volumes were calculated based on the estimated manhours for each phase and a factor of $13 \mathrm{gal} / \mathrm{employee/day} \mathrm{for} \mathrm{generic} \mathrm{industrial} \mathrm{buildings} \mathrm{(Metcalf} \mathrm{\&} \mathrm{Eddy,} \mathrm{Table} \mathrm{2-10,}$ 1962 data). 


\section{DISTRIBUTION}

1. L. V. Asplund

2. J. C. Henderson

3-4. A. K. Lee/DOE-OSTI

5. D. M. Matteo

6. D. W. McCune

7. L. W. McMahon

8-9. T. J. McLaughlin

10. H. C. Newsom

11-12. P. T. Owen

13. R.W. Weigel

14. S. A. White

15. ER Document Management Center-RC

16. R. M. Meccia, Foster Wheeler Environmental Corporation, 111 Union Valley Road, Oak Ridge, TN 37830

17-18. T. E. Myrick, Science Applications International Corporation, P.O. Box 2502, Oak Ridge, TN 37831

19. J. W. McCollum, MK-Ferguson of Oak Ridge Company, P.O. Box 2000, Oak Ridge, TN 37831 